\title{
Social Housing for Rent in Poland in the Beginning of the 21st Century. Analysis of Chosen Concepts
}

\author{
Andrzej Tokajuk \\ Bialystok University of Technology, Faculty of Architecture, ul. Sosnowskiego 11, Bialystok, Poland \\ tokajuk@pb.edu.pl \\ cross ${ }^{r e f}$ http://dx.doi.org/10.5755/j01.sace.3.4.4692
}

The period of economic transformation in Poland started from 1989 and resulted in significant changes on the housing market. Flats became goods and process of privatizing of the housing market took place in last decade of the 20th century. It became clear, that it was necessary to create the system of housing for the people who cannot afford to buy the flat on free market. Such solutions were implemented in 1995 and since then affordable housing associations started coming into existence - organizations building flats for rent, supported by city and government budget. Large complex of such housing for rent was built in Bialystok, the major city of north-eastern Poland, and it is regarded as one of the biggest in the country. The purpose of author's study is characteristics of the contemporary social housing for rent in Bialystok, as good example of that kind of housing realized in Poland.

Keywords: architecture, social housing, urban concept, housing standard, Bialystok.

\section{Introduction}

The period of economic transformation in Poland (the biggest country of Central and Eastern Europe) started from 1989 and resulted in significant changes on the housing market. Flats became goods and process of privatizing of the housing market took place in last decade of the 20th century. After a few years of economical changes, standards of new apartments diversified, a section of luxury flats appeared, gated communities became very popular. We built some housing estates which we can regard as icons of the residential architecture in Poland (e.g. Marina Mokotow in Warsaw, City of Wilanow, etc.). In these projects, realized mainly by private investors, we can find some neoliberalism philosophy accompanied by neomodernism spatial solutions or concepts coming back to the city space of 19th century (Tokajuk, 2010). It became clear, that it was necessary to create the system of affordable housing for the people who cannot afford buying the flat on free market. Such solutions were implemented in 1995 and since then affordable housing associations - Social Building Societies - started coming into existence - non-profit organizations building flats for rent (a kind of social housing), supported by city and government budget. The complex of such housing for rent was built also in Bialystok and it is regarded as one of the biggest in Poland (contains a few thousand flats). In the paper the term "social housing for rent" will be also replace by "affordable housing", as these both expressions refer to the same kind of housing in Poland.

\section{Methods}

The method used in this study is called parametrical and includes several factors describing quality of housing environment. That means analyses of urban composition of complexes, solutions of automobile and pedestrian routes, spatial concepts of surroundings, semi-public space, and recreational space, the access to the social services, architectural concepts and standards of apartments.

\section{Results}

Characteristics of the Bialystok Municipal Social Building Society. Municipal Social Building Society (in Polish - KTBS) in Bialystok was created as a limited liability company by a resolution of the city council at $28^{\text {th }}$ of October $1996^{1}$ (Barek, 2009). The aim of that company was providing possibilities of meeting housing needs for families which cannot afford purchasing own flat or a house, by the construction of dwellings for rent characterized by affordable charge. The field of activity of Municipal Social Building Society in Bialystok can moreover spread to: purchasing residential buildings, conducting repairs and modernizations of objects transformed to affordable housing for rent, renting usable floor spaces designed and owned by the Society for services or business activities, managing and mantaining housing buildings constructed and owned

\footnotetext{
1 Law Act Parliament of Poland „Certain forms of housing construction” established 25.10.1995 (Dz.U.Nr 133, poz.654)
} 
by the Society, construction of housing buildings and the accompanying infrastructure.

The limited liability company is carrying the housing policy of the authorities of the city of Bialystok, building affordable flats for rent for families with low income. It builds thanks to money coming mainly from the outside, as the long-term credits of low interest from the National Housing Fund, supported by national bank and government. Municipal authorities cover about $15 \%$ of such investments - it contains of a value of the area transferred to Municipal Social Building Society and some money for the beginning of investment. Achievements of Municipal Social Building Society in Bialystok during 15 years of activity are impressive. The company constructed until the end of 2009 about 2292 dwellings, and 2169 of them in one district of the city - called Bacieczki (Municipal Public Building Society Report, 2011). Another next 312 flats have been already planned (waiting for the building permit). In the scale of the entire country of Poland it determines $3 \%$ of the whole number of 80 thousand of dwellings realized by such Societies in the frame of that kind of affordable housing for rent from 1996) (Statistical Yearbook of the Republic of Poland, 2010).

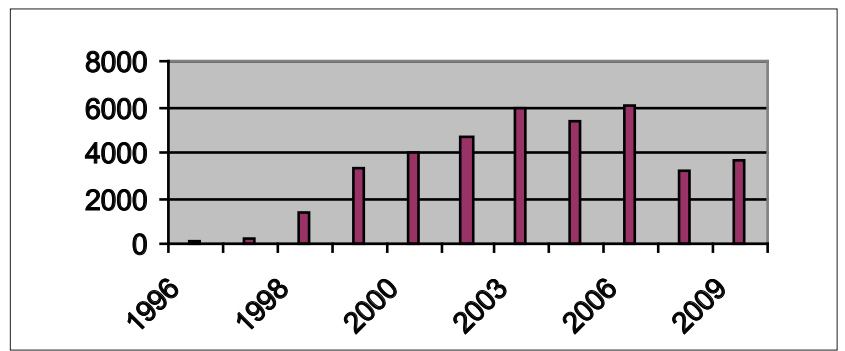

Fig. 1. Number of dwellings for rent built by Public Building Societies in Poland in chosen years. Source: Statistical Yearbooks of The Republic of Poland 1996-2010, Warsaw, Poland

Urban concepts and architectural solutions. Complexes of dwellings for rent built by Municipal Public Building Society in Bialystok are located on peripheral area of agglomeration. In addition Bacieczki I, II, III, IV and $\mathrm{V}$ are neighbors, forming the big housing district. According research made in the Faculty of Architecture Bialystok University of Technology concerning conditions of living, it seems that inhabitants do not evaluate the location negatively; in their opinion the connection with the city is good or satisfying. First small estate of 123 flats for rent was built in years 1997-1998 in district Green Hills (arch. A. Duda). It consists of three buildings forming two courtyards - one of them was designed as playground for children. A small pedestrian street is running across the development, leading to building accesses (Fig. 2, 3). The architecture is characterized by simple, modest forms, well exhibiting the straight, but interesting concept of urban space. Buildings were designed as four-storey, covered with the flat roof, in the mixed technology (partly traditional and prefabricated). Outside walls were solved as sandwich walls, 106 parking places and 14 garages were also designed near the buildings.

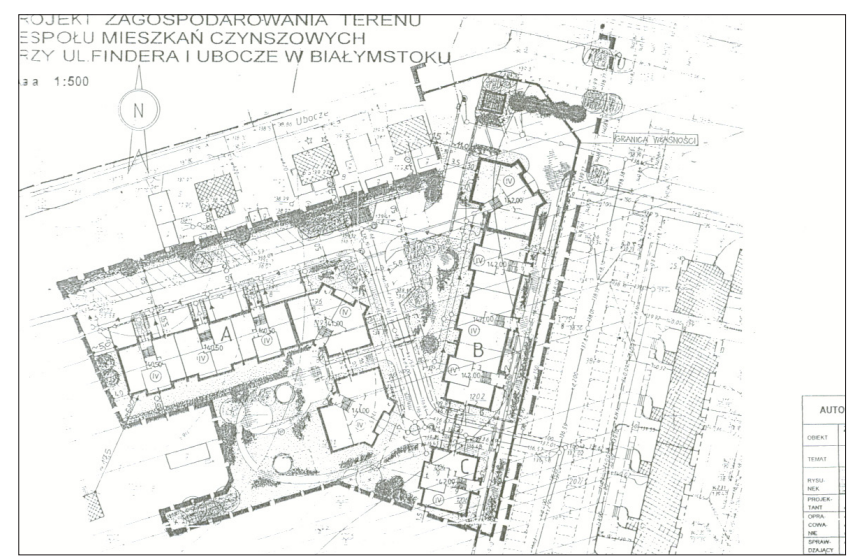

Fig. 2. Small social estate on Green Hills - urban plan

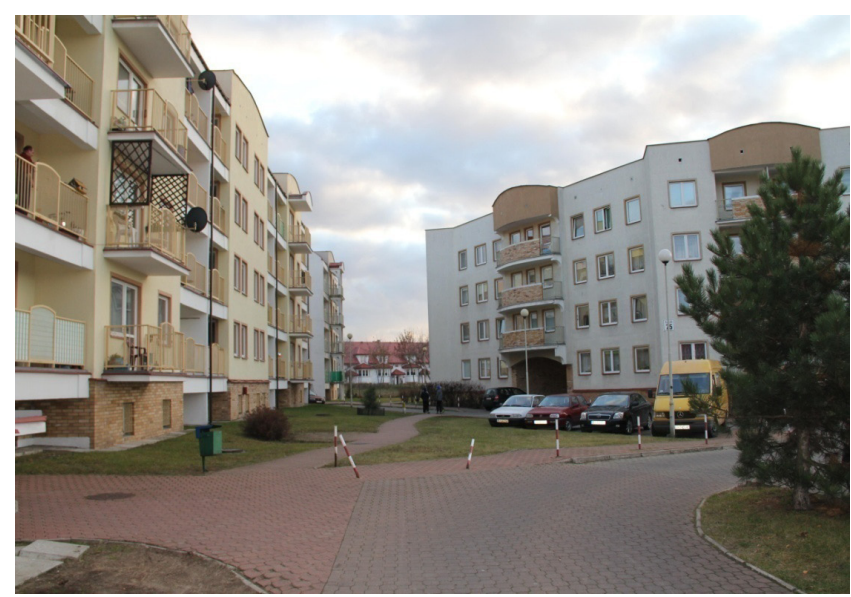

Fig. 3. Small social estate on Green Hills. View of pedestrian street and courtyard

Housing estate Bacieczki I consists of 10 buildings in the quarter surrounded by streets: H. Kollataja, W. Pileckiego and M. Pietkiewicza in the district of Bacieczki (arch. M. Szymański). Architects designed 477 dwellings $23488 \mathrm{~m}^{2}$ of usable floor space including area of services of $737 \mathrm{~m}^{2}$. The general volume of buildings is a $105108 \mathrm{~m}^{3}$. 81 single garages were located in basements. An area of the plot is $30963 \mathrm{~m}^{2}$, area of buildings $-8110 \mathrm{~m}^{2}$., paved area $12690 \mathrm{~m}^{2}$, green surfaces - $10163 \mathrm{~m}^{2}$ (30\%), including two children's playgrounds. All buildings are solved as 4-storey. Along the Kollataja Rd. double-level flats were designed (on last two floors) and some services in the ground floor. Outside walls of buildings were made in the traditional technology sandwich. Buildings have high roofs with timber structure covered with the metal sheets. The whole estate was built in 17 and half months. The main idea of urban concept is Pedestrian Street going down through the middle of whole quarter (Fig. 4). 


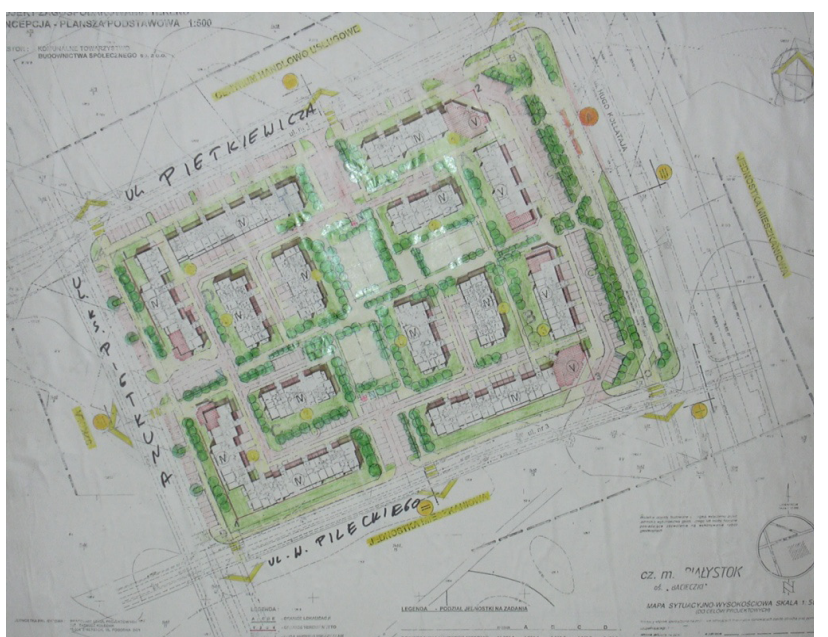

Fig. 4. Estate Bacieczki I, urban plan

Unfortunately architects allowed inhabitants to park cars inside the quarter. The traditional character of architecture is expressed by entrances to buildings, made with bricks (Fig. 5).

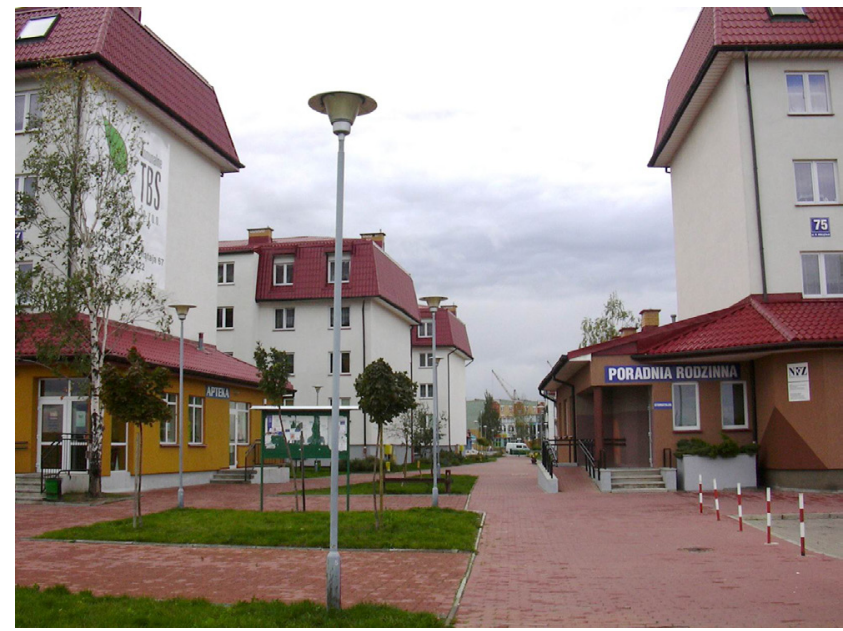

Fig. 5. Pedestrian street in estate Bacieczki I. On the first plan some services integrated with housing buildings can be seen

Urban concept of the estate Bacieczki II creates eight housing buildings located in the next quarter surrounded by street of M. Pietkiewicza and W. Pileckiego (Fig. 6). The entrance to the estate is the continuity of the pedestrian path form the former quarter.

Architects (arch. J. Naruszewicz, arch. Z. Zabaglo) designed here 403 flats; the total usable floor space is $18204.9 \mathrm{~m}^{2}$. There are some commercial and service pavilions here which have the total usable area of $740 \mathrm{~m}^{2}$, apart from them a few little shops are located in ground floors of housing buildings. The access to services and shops is available from pedestrian path mentioned above. 45 garages were also planned and made. Unlike previous estate here outside walls were made in the triple-layers technology (traditional sandwich wall), and outer layer was constructed with the sand-lime brick and clinker. However architects applied very "heavy", massive details of balconies and other elements (Fig. 7).

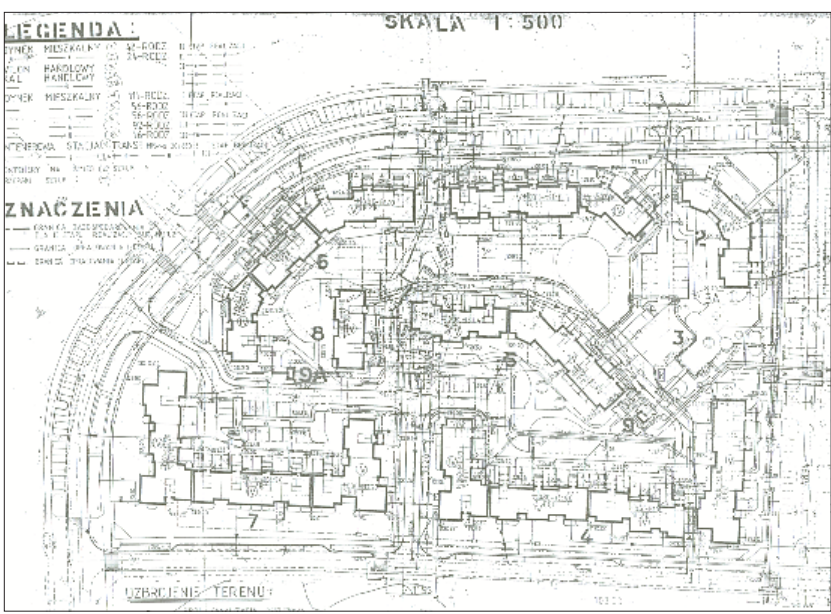

Fig. 6. Estate Bacieczki II, urban plan

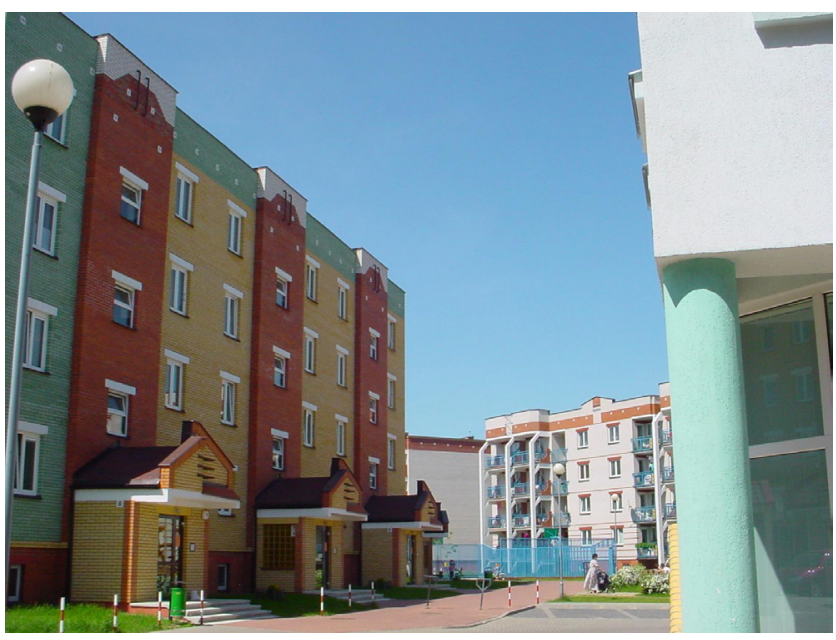

Fig. 7. The view of the housing buildings in estate Bacieczki II

The estate Bacieczki III (4 hectares of site area, 577 flats, usable floor space $25839 \mathrm{~m}^{2}$ ) was constructed in years 2003-2004 (arch. A. Duda). In the idea of urban concept there is a step forward here comparing to previous solutions. The big quarter of the 4 hectares area was divided into two smaller ones. In these quarters the building development was formed in "U" shape, opening to the east direction (Fig. 8).

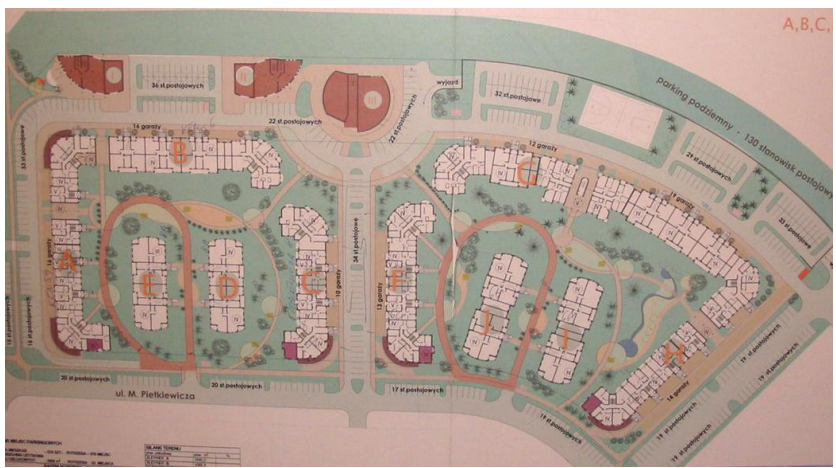

Fig. 8. Estate Bacieczki III, urban plan

Additionally in quarters linear buildings were put in east-west direction, creating semi-private urban interiors with pedestrians paths (and also the possibility 
of technical access - road). High quality construction job, good proportions, fine details, entrances (Fig. 9), outside walls finished with bricks in ground floors, soft path lines, beautiful playground for children and the sport court - these solutions give very good standard keeping up with standards fulfilled by private developers.

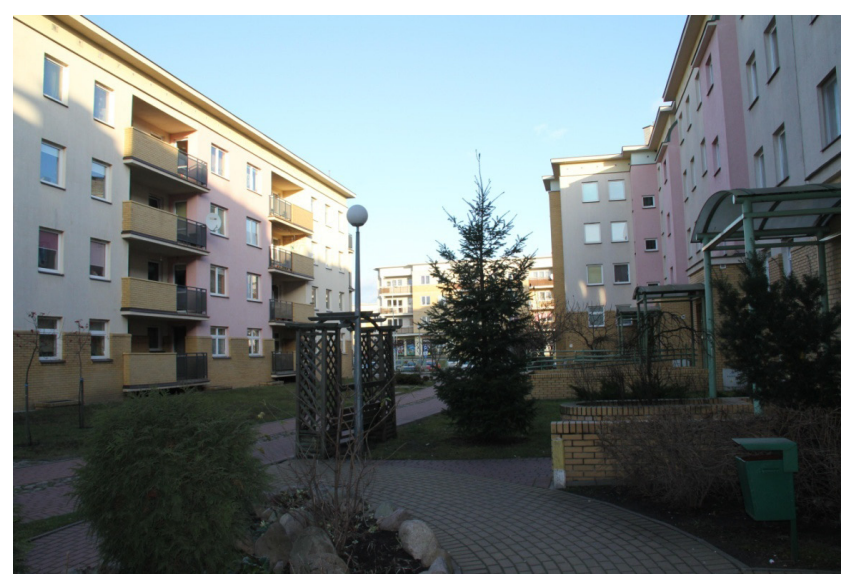

Fig. 9. Estate Bacieczki III, courtyard and entrances to housing building

An administrative building with the small kindergarten and 12 commercial spaces (usable floor area - $2556 \mathrm{~m}^{2}$ ) were also located in the estate III. Parking spaces have been provided mainly in the green belt in the west side of the area, where there is the border with the main transit road (Fig. 10). Additionally it is possible to park cars in the central strip - street dividing the quarter into two parts. With including 86 garages designers predicted all together 577 parking places what gives the proportion: one parking space suits one flat. For services and shops 52 additional parking places were planned.

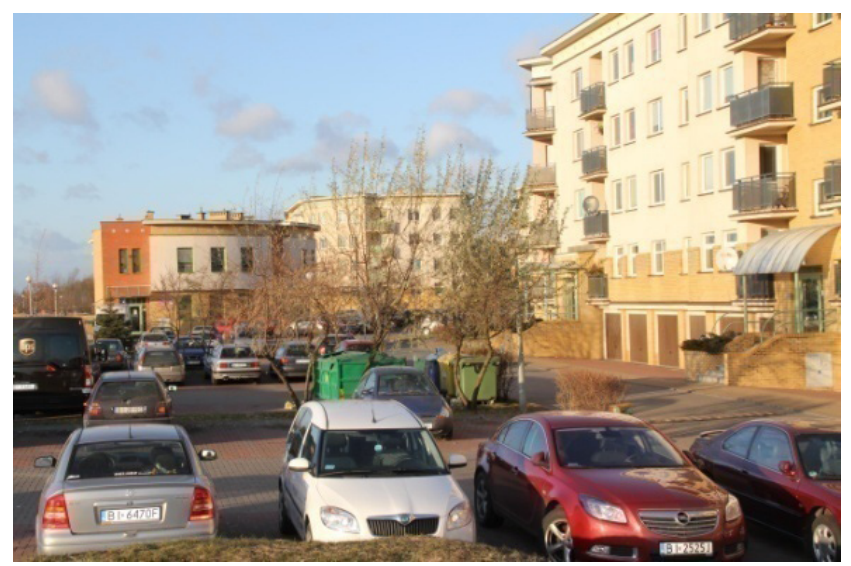

Fig. 10. Estate Bacieczki III, parking lot (first plan) and kindergarten (second plan)

The estate Bacieczki IV was constructed in years 2006-2008 (arch. Z. Zabaglo). The total area of estate is 4.5 hectares. 500 flats were designed here what gives $24313 \mathrm{~m}^{2}$ of usable floor space. The rectangular, long site of the location was divided into two smaller parts (Fig. 11).

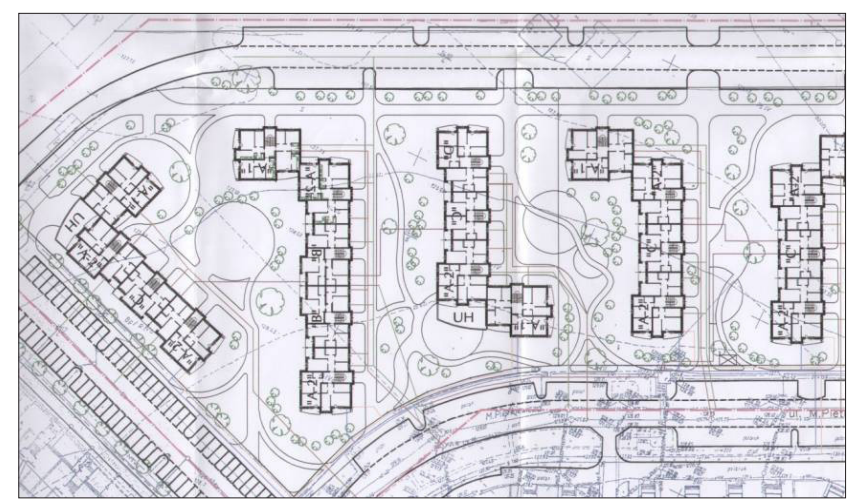

Fig. 11. Estate bacieczki IV, urban plan (North part). Clear idea based on the parallel buildings shaping inner courtyards

Communication streets were conducted around, adapting to the existing road network. In the estate 49 garages and 6 commercial pavilions were also designed (Fig. 12).

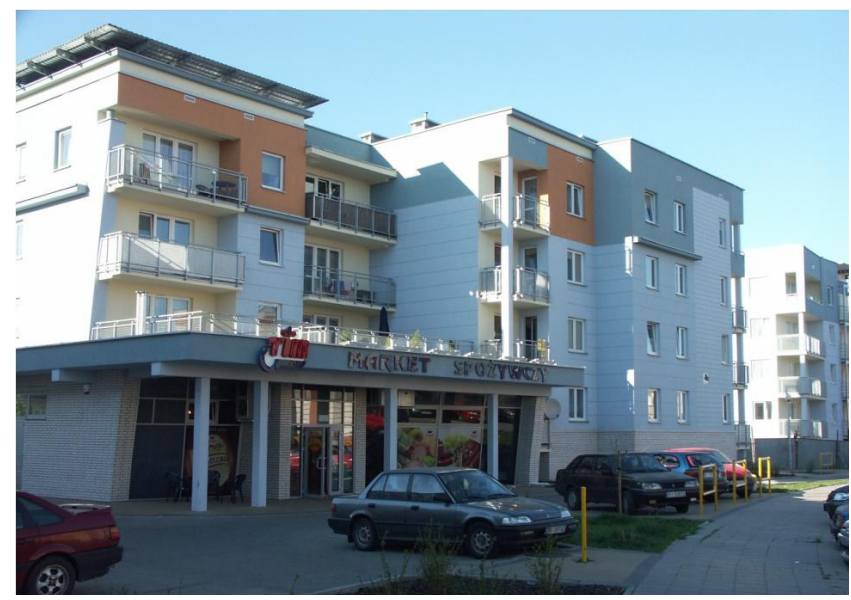

Fig. 12. Estate Bacieczki IV, shops integrated into housing building

In the first urban proposal linear housing buildings were situated parallel to each other what seemed to be monotonously and resembled modernistic estate schema coming from 20th century (Ostrowski, 1975). Finally designers changed the ideas and urban concept was created by composition of "L" shape buildings forming courtyards. These semi-public spaces have good proportions (Fig. 13).

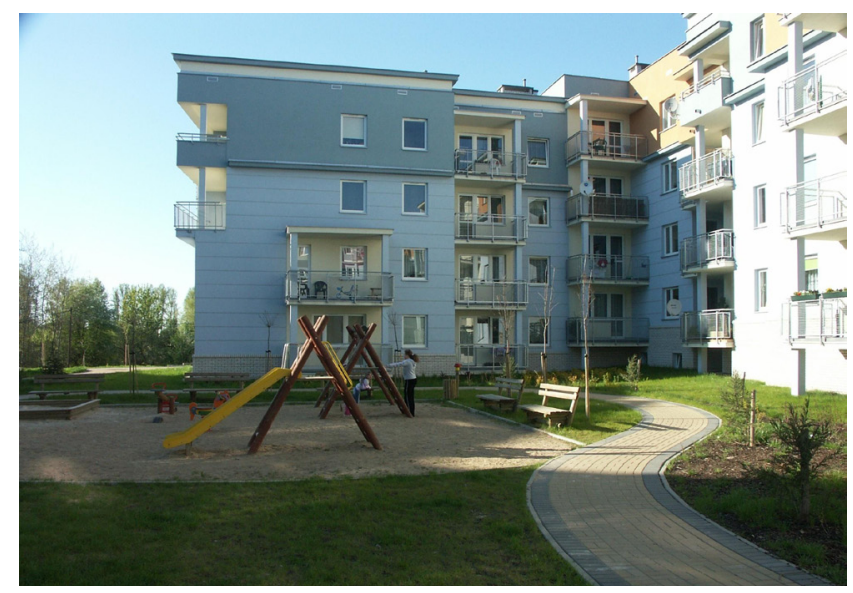

Fig. 13. The estate Bacieczki IV, courtyard view 
Buildings are composed from repeatable sections or they were solved as point houses. A good architecture of buildings is an advantage, neomodernistic trend seems to be quite pleasant for an eye, original details of balconies, loggias, entrances, interesting colors suit well to the composition of elevations.

Urban concept of the Bacieczki V, built in years 20092010, was based on the principle of creating a few small recreational courtyards in one big quarter (arch. Z. Zabaglo). At first the big quarter of the development was divided into two smaller, next designers added additional building between two parts stepped back from the forward building line. In that way two parts have been joined together. We got in the end two additional courtyards plus two main ones (Fig. 14, Fig. 15). In the quarter of the area of 1.44 hectares, 212 flats were planned with $9656 \mathrm{~m}^{2}$ of usable floor space. Also 37 garages, over 150 ground parking places and 4 services were designed (services located in ground floor corners of development). The automobile communication was designed around the rectangular quarter. The estate Bacieczki $\mathrm{V}$ is planned as a classical city quarter with development designed strictly along with the each side creating city frontages.

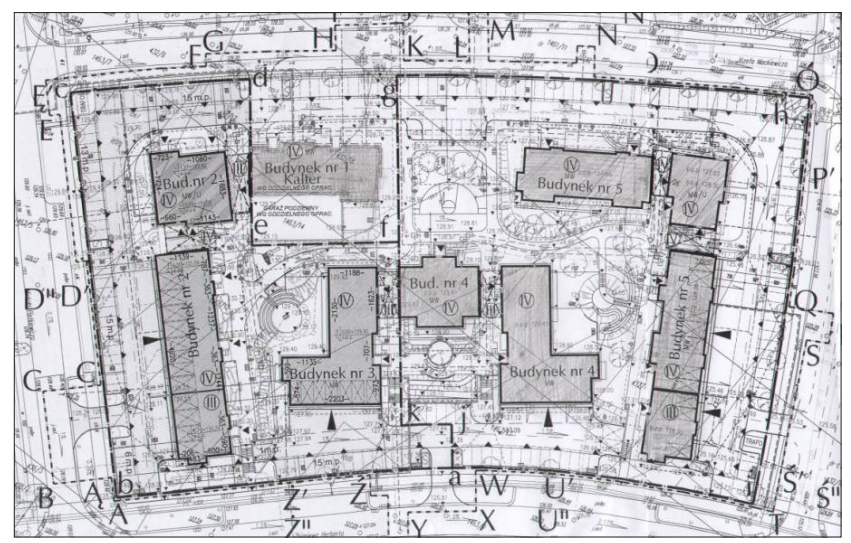

Fig. 14. Estate Bacieczki V, urban plan

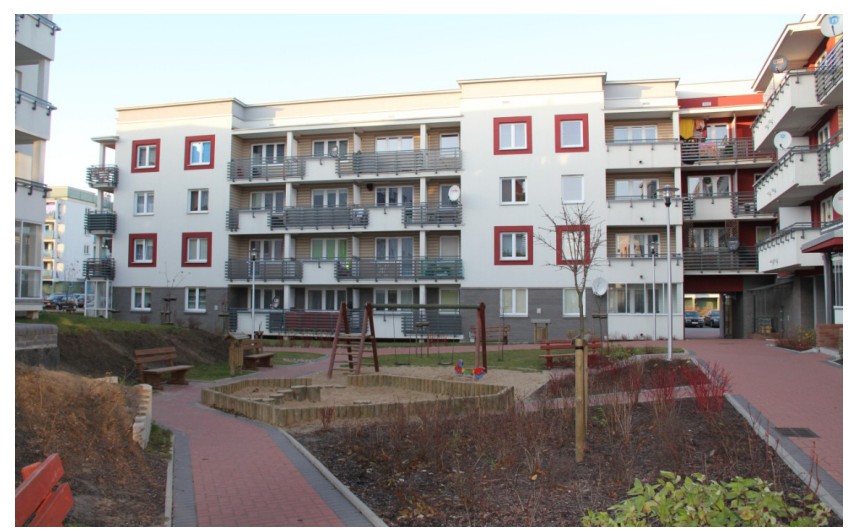

Fig. 15. The estate Bacieczki V, courtyard view

Each of analyzed estates is different from architectural point of view, but everyone is well composed urban space. In Bacieczki II it is possible to find features of regional architecture (high mansard roofs, entrances to buildings). In other estates we can see some architectural features of modernism: details and proportions. Urban concepts of estate evolved: from the one with a kind of meandric manner, group of buildings with the across pedestrian street, to the example based on courtyards and finally formed city quarter. All of them are correct from the aspect of creating good city structure - all are quarters with clear planned development (Krier, 2001). Inside them we got well formed good semipublic spaces, characterized by good scale and proportions. In Bacieczki I and II automobile communication was solved in a way allowing the traffic into interiors of quarters what caused some bad conditions of quality of semi-public spaces ( noise, air pollution). In next solutions the road traffic and parking places were designed on the borders of the site, with adequate relation to buildings. Such solution guarantees insulation form the communication noise, it gives feeling of privacy and safety what inhabitants confirm. We can reach semi-public urban interiors going throw specially shaped gates, openings between buildings, using pedestrian ways leading under the upper floors hanging over - all these helps to establish clear borders of each estate, help inhabitants to identify their own space and building (Alexander, 2008).

\section{Discussion}

Housing standards. In analyzed estates buildings solved as sectional are dominating, in Bacieczki IV we can meet also point houses. Buildings were most often designed as four-storey, without lifts, covered with the flat roof, in the mixed technology (traditional technology with elements of prefabrication). Outside walls were made as two-layered, in one case 3 - layered, sandwich types. Flats have all essential infrastructure installations: waterworks and sewerage, central heating, electrical, telephone, cable television, gas. Floors were made from PCV.

In the estate Bacieczki I and II few flats located in the ground floor were adapted to needs of persons with disabilities (ramps, lifts), but such facilities were not designed and made in front of each entrance. In estates Bacieczki III, IV and V all flats located in ground floors are available to persons with disabilities (according the Polish building codes). At first, from 1995, flats for rent were being designed based on the following surface standards (e.g. in Bacieczki I, II and III): usable floor area of 1 room apt.: minimum $25 \mathrm{~m}^{2}$; usable floor area of 2 rooms apt. - 32 $45 \mathrm{~m}^{2}$; usable floor area of 3 rooms apt. $-52-64 \mathrm{~m}^{2}$.

In 2 rooms flats a bed to sleep was planned in a living room, so it was possible to settle in it from 1 to 3 persons; in 3 rooms flat - from 3 to 5 persons could live. After a few years this situation changed; the government stopped such regulations, now the future tenant - the user (single, couple or family) - decides, what type of the flat for rent he is applying for. The following standards are available: 1room flat - up to $40 \mathrm{~m}^{2}, 2$ rooms flat - up to $50 \mathrm{~m}^{2}, 3$ rooms flat - up to $70 \mathrm{~m}^{2}, 4$ rooms flat - up to $90 \mathrm{~m}^{2}$. These values are approaching rates in the commercial housing industry.

At present in estates with dwellings for rent in Bialystok there are a few types of flats, but the majority of such flats are 2 rooms apartments - over $60 \%$ (1 bedroom, living room, kitchen and bathroom), with average usable floor space of $50.1 \mathrm{~m}^{2}$ each one ${ }^{2}$.

Statistical Yearbooks of The Republic of Poland 2010, Warsaw, Poland 
Table 1. The structure of dwellings in Municipal Public Building Society in Bialystok (Poland) in 2003 and 2010. Source: Author's estimation based on reports of MPBS in Bialystok from 2003, 2010

\begin{tabular}{|l|l|l|l|l|}
\hline Category & $\begin{array}{l}1 \text { room } \\
\text { apt. (living } \\
\text { room with } \\
\text { bed) }\end{array}$ & $\begin{array}{l}2 \text { rooms } \\
\text { apt. (1Br } \\
\text { + living } \\
\text { room with } \\
\text { bed) }\end{array}$ & $\begin{array}{l}3 \text { rooms } \\
\text { apt. (2Br } \\
\text { + living } \\
\text { room with } \\
\text { bed) }\end{array}$ & $\begin{array}{l}4 \text { rooms } \\
\text { apt. (3Br } \\
\text { + living } \\
\text { room with } \\
\text { bed) }\end{array}$ \\
\hline $\begin{array}{l}\text { dwellings in } \\
2003\end{array}$ & $35 \%$ & $50,5 \%$ & $8,5 \%$ & $6 \%$ \\
\hline $\begin{array}{l}\text { dwellings in } \\
2010\end{array}$ & $19 \%$ & $62 \%$ & $14 \%$ & $5 \%$ \\
\hline
\end{tabular}

Green Hills housing estate is smallest from mentioned below. From the whole number of 123 flats located there as many as 42 of them are small ones (1 room apt.) and only 8 of them have 3 rooms ( 2 bedrooms and living room).

Table 2. The structure of dwellings in chosen estates of Municipal Public Building Society from Bialystok, Poland. Source: Author's estimation based on reports of MPBS in Bialystok from 1997-2010

\begin{tabular}{|l|l|l|l|l|}
\hline Category & $\begin{array}{l}1 \text { room } \\
\text { apt. (living } \\
\text { room with } \\
\text { bed) }\end{array}$ & $\begin{array}{l}2 \text { rooms } \\
\text { apt. (1Br } \\
+ \text { living } \\
\text { room with } \\
\text { bed) }\end{array}$ & $\begin{array}{l}3 \text { rooms } \\
\text { apt. (2Br } \\
\text { + living } \\
\text { room with } \\
\text { bed) }\end{array}$ & $\begin{array}{l}4 \text { rooms } \\
\text { apt. (3Br } \\
+ \text { living } \\
\text { room } \\
\text { with bed) }\end{array}$ \\
\hline $\begin{array}{l}\text { Green Hills } \\
\text { estate }\end{array}$ & $34 \%$ & $53 \%$ & $13 \%$ & $0 \%$ \\
\hline $\begin{array}{l}\text { Bacieczki I } \\
\text { estate }\end{array}$ & $40,5 \%$ & $52 \%$ & $6 \%$ & $1,5 \%$ \\
\hline $\begin{array}{l}\text { Bacieczki II } \\
\text { estate }\end{array}$ & $29 \%$ & $61 \%$ & $10 \%$ & $0 \%$ \\
\hline $\begin{array}{l}\text { Bacieczki III } \\
\text { estate }\end{array}$ & $3,6 \%$ & $67,8 \%$ & $17,6 \%$ & $11 \%$ \\
\hline
\end{tabular}

The similar situation is appearing on the estate Bacieczki I - from the total number of 479 flats, 194 ones are small (1 room apt.), only 30 flats have 3 rooms ( 2 bedrooms and living room). Here bigger flats started to be constructed -4 rooms apt., with 3 bedrooms and living (6 dwellings). Proportions of the quantity of flats depending on their size changed on the estate Bacieczki II. Over half of total number of 403 flats have 2 rooms - 1 bedroom and living (247 apt.) there.

According to interest of future tenants a share of 2rooms and 3 rooms flats is rising. At present the area of flats in estate of Municipal Public Building Society in Bialystok fluctuates from $33.1 \mathrm{~m}^{2}$ up to $101.4 \mathrm{~m}^{2}$.

Flats in all analysed estates were being designed as well-distributed, zonal spatial ones. A model of a daily open space has often been applied in dwelling projects carried out last years, with kitchen located in annex lighted indirectly. Some larger flats ( 2 and 3 - bedrooms) are equipped with wardrobes. In older solutions closed, directly lighted kitchens were designed. Almost all types of flats inhabitants assessed as functional. Inhabitants didn't have a lot of remarks concerning solving the functions of flats, a smaller bathrooms design was suggested in small 1 room flats ( less than $6 \mathrm{~m}^{2}$ ), and at the same time increasing the living space. In several cases there were some trouble with ventilation of rooms, therefore in flats under construction now windows are being assembled with special air ventilators. We must notice, that in every country belonging to European Union social dwelling is defined in a different way. It is a condition of possibility to get governmental financial support. Poland only after the accession to the EU established its own definition - in 2007 ( Barek, 2009). Such flats have been rated lower tax for many years.

Housing environment. In all housing estates with social dwellings for rent in Bialystok they managed to get good quality of the housing environment - inhabitants confirm that harmony. Fine materials and construction works complement the whole project. Modern playgrounds and sport courts were carried out . Certain remarks of inhabitants concern the Bacieczki I estate, where some playground arrangement and toys were made from metal elements (they aren't adapted to small children); there are too many surfaces of details finished with hard concrete elements - a possibility of injury in case of falling for the child is increasing. In all examples parking spaces had been designed, at present in proportion one parking space for one flat - because it turned out that in already existing estates the number of parking places is not enough.

A lot of trees and other new plants started to grow on areas of mentioned case studies, but the greenery has not managed to grow yet, therefore inhabitants asked, that a park would be useful in the close neighborhood. Administrations of the Society managed to fulfill these suggestions. In the years 2008-2009 a recreational park in the insulating belt of the main road was established, equipped among others with some arrangements for children and young people (Fig. 16). They also made small gated area for dogs owners. A park has the area 1.88 hectares (arch. Z. Zabaglo) and it became fine example of public space integrated with housing district (Gehl, 2009).

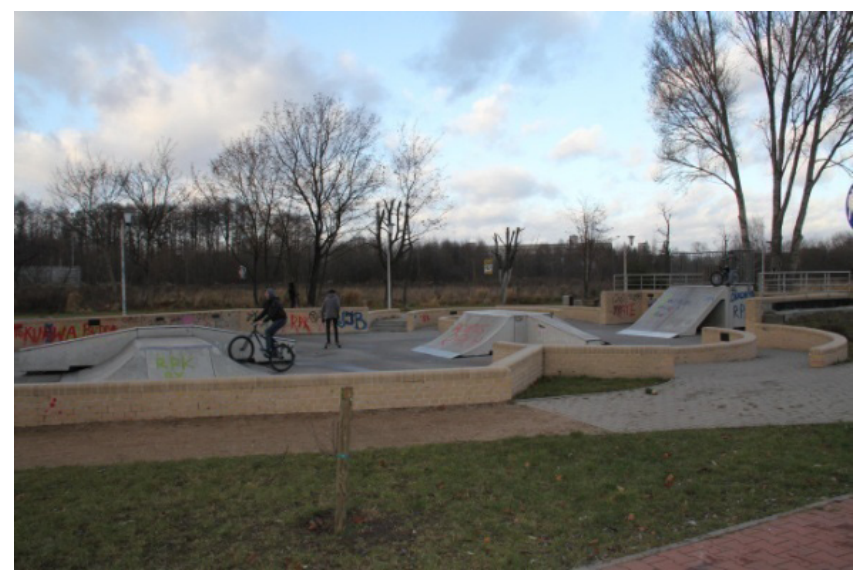

Fig. 16. Skate park located in the green recreational zone (small park)

In estates belonging to Municipal Public Building Society there are too short bicycle lanes. Except for the garbage sorting, the environment-friendly solutions, e.g. using the unconventional sources of energy, weren't implemented.

Respondents sometimes emphasized the appearing monotony of the building development, because of applying 
only 4 storey buildings - repeated several times in the Bacieczki I and II. Buildings do not differ one from another so much (only a color of balconies, balustrades, brick color), even entries to staircases are the same. The situation has been improved and became more comfortable in estates built later, there are two types of buildings in the estate, but buildings were situated too close to each other.

There are service-commercial spaces in all estates. On Green Hills the number of them is 3 ( 3 and basement used as a studio). In Bacieczki I and II - we can find there 31 commercial spaces, including the administration office of Municipal Public Building Society and two rooms which were rent for student sports club free of charge who are constructing the fitness room and the recreational day room for young people. Apart from little shops there are also post office, bank, dentist's surgeries, clinic of family doctors, private nursery school in these estates. Not so far away the secondary school was built, a primary school is located in an old part of the housing estate, a little bit moved away from Municipal Public Building Society (a few hundred meters in a straight line).

\section{Conclusions}

Complexes of affordable dwellings for rent carried out in Bialystok in years 1996 - 2011 are good, valuable solutions of that type of social housing. Every next quarter which was built carried higher architectural and urban standards. Particularly Bacieczki I-V estates are interesting examples, located next to each other, they form large housing complex ( 2169 flats). Although mentioned estates were not designed as the whole one area from the beginning, according to one master plan - they create district of good neighbourhoods (with right spatial and functional relations). In the future Municipal Public Building Society plans to realize one more housing quarter - Bacieczki VI, with 312 flats. The architectural project has been already made and the list of 1500 families waiting for such flats in the city town hall is a guarantee of success of this investment. Main conclusions from the research are: affordable social housing for rent constructed in Bialystok create the city of good neighborhoods with clear urban quarters realize proper standard of housing buildings by using good quality materials and details, achieve very fine spatial design of semi-public and recreational spaces (even a small park). All flats located in ground floors are available for disabled inhabitants. As a positive feature we can count location of parking places, providing some basic services, shops, kindergarten and school (the last one was planned in master plan and realized not by the Society but by the city). During research inhabitants responded that they like living in such housing environment and accept its standards. Despite of neoliberal tendencies in private commercial housing in Poland (investors often build apartments without any social infrastructure!) - affordable housing Bacieczki district in Bialystok is positive example of social housing for rent with some aspects of sustainable development (spatial, economical, social).

Of course we can evaluate that standards of usable surface of flats is rather low, we would expect larger flats planned for families with children, providing flats for young people, smaller quarters with more individual architectural character and identification. The question arises, if affordable housing should give new spatial and architectural standards or should provide housing on good or high level? It seems that what we really need more is seeking forms suitable for peripheral locations and apply environmentfriendly solutions (technical and structural-material), allowing more economical exploitation of buildings. It is a pity, but the program of such type of housing in Poland is in danger at the moment, because of financial crisis. The government plans to sell flats of Public Buildings Society (make privatization process)! In spite of it, this Polish model of affordable housing for rent is worth promoting in other developing countries with huge housing needs.

\section{Acknowledgment}

The analysis was carried out in the frame of scientific work financed by the Polish Ministry of Science \& High Education in the years 2010-2012 as research project No. N N527 075838.

\section{References}

Alexander Ch. 2008. Jezyk wzorcow. Gdansk, GWP.

Barek R. 2009. Architektura środowiska mieszkaniowego tworzonego z udziałem środków publicznych. Poznan, Wydawnictwo Politechniki Poznanskie.

Gehl J. 2009. Zycie między budynkami. Uzytkowanie przestrzeni publicznych. Krakow, Wyd. RAM.

Krier L. 2001. Architektura. Warszawa, Wybór czy przeznaczenie. Arkady.

Municipal Public Building Society Report. 2011. Bialystok, Poland.

Ostrowski W. 1975. Urbanistyka współczesna. Warszawa, Arkady.

Statistical Yearbook of the Republic of Poland. 2010. Warsaw, Central Statistic Office, 350-363

Tokajuk A. 2010. Tendencies in Developing Urban Concepts of Multi-Family Housing Complexies in Poland of the Beginning of XXI Century. In: Advanced Construction: proceedings of the 2nd International Conference, Kaunas University of Technology, 11-12 November, 2010, Kaunas, Lithuania, 75-86

Andrzej TOKAJUK - associated professor at Bialystok University of Technology, Faculty of Architecture.

Main research area: multifamily housing, residential architecture, revitalization processes, sustainable development, urban design and city structure, theory of architecture.

Address: ul. Oskara Sosnowskiego 11, 15-893 Bialystok, Poland.

Tel.: $\quad+48857469910$

E-mail: tokajuk@pb.edu.pl 